\title{
Educação e arte: a consolidação de um campo interminável ${ }^{1}$
}

\author{
Marcos Villela Pereira²
}

\section{Resumo}

O objetivo deste artigo é explorar algumas considerações acerca da educação, da arte e da relação entre elas, de modo a mostrar a condição interminável desse campo de estudo e investigação. Tomando como horizonte a formação de professores, reitero uma remessa ao entrecruzamento dos processos de subjetivação e o entendimento estético: a estética da existência como tema clássico na história da humanidade e a formação como um complexo e multifacetado processo de produção de subjetividade - formar os outros e formar a si mesmo como uma intrincada arte de existir. O lugar da arte na educação, a relação entre arte e educação, o lugar da arte na vida, o sentido da educação, as implicações entre a vida, a arte e a educação, quem vem antes, quem vem depois, quem depende de quem, quem se serve de quem: não tanto o conteúdo dessa problematização, não tanto as respostas, mas é o próprio movimento de perguntar que interessa ser problematizado. Como corpus de problematização, serão tomados quatro textos da importante arte-educadora brasileira Noêmia Varela, professora da Escolinha de Arte do Recife: "Criatividade na escola e formação do professor", de 1972; "Movimento Escolinhas de Arte: imagens e idéias", de 1973; "O desafio da formação de recursos humanos para a educação através da arte", de 1977; e "A formação do arte educador no Brasil", de 1984. O material será confrontado com categorias contemporâneas do campo da educação e da arte, buscando-se especular seu potencial infinito de investigação.

Palavras-chave: educação e arte; educação estética; ensino de arte

\begin{abstract}
The aim of this paper is to explore some ideas about education, art and its relationship, showing the condition of this endless study and research field. Taking the teacher education as horizon line, repeats a subjective processes and aesthetic understanding crossing referral: the aesthetics-of-existence as a human classic theme and teacher-training as a complex and multifaceted process of subjectivity. The place of art in education, the relationship between art and education, the place of art in life, the meaning of education, the implications between life, art and education, who comes before, who comes after, who depends on who, who serves as that: not so much the content of this problem, not so much the answers, but the movement itself to ask that matters be problematized. As corpus of reflexion will be taken four texts of Noemia Varela, an important brazilian art-educator: "Criatividade na escola e formação do professor", of 1972; "Movimento Escolinhas de Arte: imagens e idéias", of 1973; "O desafio da formação de recursos humanos para a educação através da arte", of 1977; and "A formação do arte educador no Brasil", of 1984. The material will be confronted with contemporary categories of the field of education and art, seeking to speculate its infinite potential for research.
\end{abstract}

Key-words: education and art; aesthetic education; art teaching

\footnotetext{
${ }^{1}$ Este artigo foi a base do Trabalho Encomendado para o GT-24 (Educação e Arte) apresentado na 31a Reunião Anual da ANPED, em Caxambu, em 2008. Uma versão com alguns ajustes está publicada na Revista Iberoamericana de Educação (número 52 - monográfico "Educación Artística" - jan./abr. 2010). Versão revisada para publicação neste periódico.

${ }^{2}$ Licenciado em Filosofia, Doutor em Educação, Professor Titular e Coordenador do Programa de Pós Graduação em Educação em Educação da PUCRS - Pontifícia Universidade Católica do Rio Grande do Sul. Secretário Geral e Presidente da FAEB - Federação dos Arte Educadores do Brasil - de 1989 a 1991 e de 1992 a 1994, respectivamente.
} 
Minha idéia é explorar algumas considerações acerca da educação, da arte e da relação entre elas de modo a mostrar a condição interminável desse campo de estudo e investigação. E pretendo fazer isso não por diletantismo, mas por querer fazer ver que algumas questões fundamentais que temos posto em nosso contexto exigem sempre e sempre a sua colocação, a cada nova circunstância. Por querer fazer ver que mesmo quando estabelecemos alguns princípios ou valores de modo universal - ou, no mínimo, quando pretendemos fazer generalizações - ainda assim estamos postulando um entendimento que exige uma tomada de posição ou a demarcação de uma perspectiva em relação à qual compreendemos a realidade. Porque mais importa o modo como operamos com essas questões do que as respostas que damos a elas, cada vez que as colocamos.

Há muitos anos, meu objeto de investigação é a formação de professores. E tenho sido recorrente na remessa que faço a esse entrecruzamento entre os processos de subjetivação e o entendimento estético. Aliás, nada original: a estética da existência é tema clássico na história da humanidade. A formação como um complexo e multifacetado processo de produção de subjetividade. Formar os outros e formar a si mesmo como uma intrincada arte de existir.

Em outra ocasião (PEREIRA, 1996) já defendi a necessidade de pensar a formação de professores orientada pela problematização e pela crítica: evitando recair na discussão de modelos ou modos de ser professor, propus inquirir como nos tornamos professores. E essa pergunta não se dirige à identidade do professor, não é ao conteúdo da professoralidade, não são as habilidades, as competências ou os saberes que persigo com a inquietação. É o como se chegou a ser o que se é. Trata-se, sim, de pesquisar os movimentos de professoralização para podermos nos aproximar de entender a professoralidade, da mesma maneira que se trata de pesquisar os movimentos de subjetivação para podermos nos aproximar de entender a subjetividade (PEREIRA, 1997).

Entendendo a professoralidade como uma marca, um estado singular, um efeito produzido no (e pelo) sujeito (PEREIRA, 1996), somos levados a entender que os movimentos de constituição de si (a estética) produzem num mesmo lance o sujeito e o professor. O sujeito se professoraliza e se subjetiva ao mesmo tempo. $E$, ao se professoralizar, contribui para a subjetivação de outros sujeitos.

O professor, como agente da pedagogia e da didática, é um sujeito orientado por princípios, comprometido com a justiça e com o bem. Ele é um agente de formação 
de outros sujeitos. Entretanto, não se trata de tomar por referência um bem único e universal. O bem nem sempre é um só nem sempre é o mesmo: mesmo a melhor concepção de bem vale apenas por um determinado período ou para um determinado contexto, além do que nunca existe uma única concepção sobre um mesmo período (OELKERS, 2007). Cada circunstância vai gerar exigências muito além de apelos morais. Cada circunstância representa uma mudança e uma progressão motivada pelos problemas daquele tempo e daquele lugar e, portanto, não se pode recair em concepções dogmáticas ou canônicas do que seja " 0 " bem. A idéia de bem é uma resposta a um problema moral momentâneo: uma nova situação gera um novo problema e, conseqüentemente, suscita outra forma de bem (OELKERS, 2007: 227). Assim, aquilo a que se dirige o trabalho de um professor é uma realidade ela mesma em permanente transformação.

Diferentes contextos culturais constituem e são constituídos por diferentes formas de racionalidade. Essas formas de racionalidade não são construções abstratas alheias à condição histórica ou política, não são pressupostos universais ou princípios absolutos. De outro modo, são formas de racionalidade cultural, histórica e politicamente construídas. Referindo-se à realidade que se estabelece a partir do século $X X$, Wolfgang Welsch diz que não existe mais nenhuma pergunta que não seria respondida de forma diferente por diferentes paradigmas ou culturas. A validade das constatações feitas no interior de uma versão de mundo é relativa às premissas dessa versão: no contexto das premissas escolhidas, as afirmações fazem sentido; no contexto de outras premissas, não (WELSCH, 2007). Segundo ele, formas de racionalidade são sempre associadas com práticas culturalmente compartilhadas e, inversamente, culturas podem ser concebidas como formas de racionalidade estabelecidas (WELSCH, 2007: 251).

Essa idéia de que uma verdade sobre o mundo corresponde a um sentido produzido no contexto de uma determinada experiência nos conduz à experimentação de um pluralismo, de um relativismo que nada tem de permissivo ou leviano, como tentaram nos fazer crer os postulantes do pós-moderno apocalíptico (PEREIRA, 2008). Esse relativismo exige um debate crítico rigoroso que nos coloque frente a frente com a nossa própria cultura e nossas próprias formas de racionalidade, com nossos próprios exercícios de racionalização. Ao contrário de nos conduzir na direção de um relativismo absoluto, relaxado e preguiçoso (o que seria efeito de um pensamento absolutista), somos levados por Wolfgang Welsch na direção daquilo que ele chama de "relativismo esclarecido", um exercício de autocrítica no interior de uma realidade transcultural (WELSCH, 2007: 250). 
Enfim, questões filosóficas nos assaltam, problemas morais nos aparecem, fazemos escolhas para nós, para a humanidade e para o mundo, constituímos um olhar sobre a realidade, sobre os outros e sobre nós mesmos na direção de alcançar uma existência boa, justa e verdadeira.

Temos nas mãos, como resíduo dessa análise, a idéia de que a realidade não tem uma verdade ou um sentido em si, já que não identificamos a possibilidade de alguma instância essencial que assegure a permanência das supostas formas universais do pensamento sobre o mundo. Temos diante e em torno de nós uma realidade que resulta de um sentido que lhe é atribuído pelo sujeito que a experimenta. Uma realidade, como diz Zigmunt Bauman, líquida (BAUMAN, 2000). Uma realidade que se arranja segundo uma forma de racionalidade que sobre ela se debruça. Não mais uma única forma de racionalidade, uma razão universal, mas uma realidade que se produz na própria experiência do sujeito que, ao existir, fabrica diferentes formas de racionalizar o mundo.

Do sujeito, podemos postular o ethos, a atitude, os princípios. Mas não o conteúdo desse ethos. Tomados pela insegurança produzida pelo fato de que uma mesma idéia pode ser verdadeira em um certo contexto e ser falsa em outro contexto, diante da incerteza frente ao fato de que algo pode representar o bem em uma circunstância e não o ser em outra, contagiados pelo desconforto ante aquilo que existe e suas implicações no que ainda virá a existir, confrontados com o pluralismo de sentidos, somos tentados a sobrepor à realidade uma impossível aparência homogênea. Porém, é o exercício da crítica e da autocrítica, que nos permite desviar dessa ilusão e conhecer, compreender e demarcar as diferentes formas de racionalidade possíveis implicadas na nossa experiência do mundo.

Ou seja, nossa pergunta pelos nossos processos de subjetivação e de professoralização representam uma via bastante importante para assumir a formação e a auto-formação como processos infindáveis. Tomar distância de si sem desprender-se de si é a condição de possibilidade de colocar em questão os princípios que orientam nossa ação sem recair em generalizações. Colocar em questão os processos e modos de subjetivação e professoralização, seus contextos, suas circunstâncias, as formas de racionalidade que neles operam, os projetos que deles emergem, os efeitos produzidos, tudo ajuda a renovar constantemente os valores que entram em cada composição. 
Essas composições nunca são definitivas nem tampouco seus efeitos se realizam completamente. Justamente porque os efeitos pretendidos - em si e nos outros não se realizam, se torna imperioso nunca abandonar o processo formativo (e autoformativo). Que o efeito pretendido não se realize, isso é justamente uma felicidade, é bom e, de modo algum, um motivo para abandonar toda a atividade (OELKERS, 2007: 228). Ao contrário, é justamente esse o mote para permanecer aprendendo com o processo de subjetivação e continuar renovando a necessidade do bem como horizonte dos processos de formação.

A educação, assim compreendida, constitui-se uma permanente experimentação do bem como ethos crítico formativo dos sujeitos. E o professor, um sujeito privilegiadamente posicionado na coincidência das condições de agente e agido.

Essa interminável tarefa empurra os sujeitos na direção de uma condição de vida que lhes dá a propriedade de ação e paixão ao mesmo tempo. O grande mote do trabalho de formação, assim, aparece como uma imensa vontade de poder viver para fazer viverem os outros, de saber aprender para levar a aprenderem os outros. Motivação prometeica de roubar o fogo aos deuses para dar aos homens, mas com a característica do trabalho de Sísifo: nunca suficiente, nunca o bastante, nunca esmorecendo, sempre suspeitando, cada vez inventando o mundo e inventando-se para estar nesse mundo e inventar-se com os outros.

Nesse sentido é que quero dizer que nossa tarefa é interminável, que nosso campo é infinito: porque não há um ponto derradeiro, um valor ou uma verdade ou um juízo definitivo a que se possa chegar. Mas, então, que rumos dar à pesquisa e ao estudo sobre a formação?

Minha proposição é que nos posicionemos atrás das sempre colocadas questões e nos preocupemos não tanto com as respostas, mas como o modo como lidamos, como temos lidado com as perguntas, com os efeitos que as perguntas produzem em nós, com os arranjos que fazemos a partir das perguntas, com os jeitos como lidamos com os problemas.

O lugar da arte na educação, a relação entre arte e educação, o lugar da arte na vida, o sentido da educação, as implicações entre a vida, a arte e a educação, quem vem antes, quem vem depois, quem depende de quem, quem se serve de quem: não tanto o conteúdo dessa problematização, não tanto as respostas, mas é o nosso movimento que me interessa sobremaneira aqui. 
A essa atitude tomada no ato de colocar-se essas questões como questões formativas, de dar trato didático ou pedagógico a elas, de experimentá-las como uma problematização radical, no sentido de ensinar algo e de aprender algo, a essa atitude chamo professoralização. Ao envolver-se com uma problemática dessa complexidade com vistas a formar-se e formar os outros, chamo de professoralização. Ao fazer coisas, ao usar táticas, técnicas, truques, ao tomar providências para proporcionar vida para si e para os outros em um campo que envolve arte e que envolve educação, chamo professoralização. Ao fazer escolhas, ao tomar atitudes, ao mexer no espaço, ao organizar o tempo, ao usar coisas, objetos, conteúdos, ao tomar, ajudar a tomar e encaminhar decisões, à partilha dessa experiência na direção de intencionalmente produzir efeitos em si e nos outros chamo professoralização.

Chamo professoralização à operação proposital de certas tecnologias, certos aparatos e certos artefatos no sentido de pôr em movimento processos e percursos formativos, para si e para os outros. E é estudando a professoralização que alcanço vislumbrar a professoralidade. É investigando como me tornei o professor que sou, por que me tornei o professor que sou é que investigo a professoralidade. 0 professor que sou, o professor que estou sendo é apenas um estado, um estágio, um efeito dessa professoralidade que se professoraliza. Aquilo que sou é um caso particular de um vasto leque de possibilidades de eu ser. A realidade é um caso particular do possível.

E não se trata, então, de esgotar a investigação desse caso particular como se ele fosse uma totalidade. O que é, o é relativamente. A mim importa olhar para o que é ao lado do que foi e do que poderia ter sido: aí, sim, me aproximo de entender a complexidade do que somos nós. Aí está o sentido do interminável: porque não é sobre a finitude do que existe que colocamos nossa atenção, mas na ilimitável e interminável existência das possibilidades. Parafraseando T. S. Eliot, digo: o que poderia ter sido e o que foi permanecem, perpétua possibilidade ${ }^{3}$.

No caso de aproximar-me da arte, me importa entender como tenho dado conta dos elementos, objetos, experiências, práticas e processos artísticos implicados nos percursos e processos de formação - a minha e a dos outros. Esse, então, é o sentido de perguntarmo-nos pela relação entre a educação e a arte.

${ }^{3}$ T.S. Eliot. Quatro quartetos - Burnt Norton In: Poesia (trad. Ivan Junqueira). Rio de Janeiro: Nova Fronteira, 1985. 


\section{Relações entre educação e arte}

Vou servir-me de questões já muitas vezes colocadas para exercitar meu olhar sobre como temos lidado com elas em diferentes momentos e, se possível, tirar algum proveito para o que temos agora. Vou escolher uma voz, uma voz que entoa legitimamente, como ninguém, essa ladainha. Ladainha no bom-sentido, sem nenhum tom pejorativo. Ao contrário, ladainha como canto, como toada, com propriedade e harmonia. Vou escolher uma voz para fazer essas perguntas pela relação entre a educação e a arte, a voz de Noêmia Varela. A meu ver, ninguém melhor do que ela para ser invocada: um ícone, um paradigma desse universo, talvez a mais importante arte-educadora brasileira. Noêmia Varela nasceu em 1917. É a criadora, em 1953, ao lado de Augusto Rodrigues e Aloísio Magalhães, da Escolinha de Arte do Recife. Posteriormente, diretora técnica da Escolinha de Arte do Brasil, através dos Cursos Intensivos de Arte Educação, Noêmia foi a grande influenciadora do Ensino da Arte em direção ao desenvolvimento da Criatividade, que caracterizou o Modernismo em Arte Educação (BARBOSA, 2003).

Vou tomar quatro textos e deles extrair excertos para comentar. Vou fazer um pouco desse exercício de ensaiar o interminável movimento entre o que poderia ter sido e o que foi.

E o curioso é que essa sua voz me chega, também, por outras vozes: eis aí outro traço da projeção en abîme, do eco que fabrica profundidades intermináveis. São as vozes de Lucimar Bello, de Ana Mae Barbosa e de Marly Meira que me fazem chegar a voz de Noêmia Varela. Os textos, "Criatividade na escola e formação do professor", de 1972 e "Movimento Escolinhas de Arte: imagens e idéias", de 1973, estão reproduzidos no livro Noêmia Varela e a Arte, de Lucimar Bello (FRANGE, 2001); o texto "A formação do arte educador no Brasil", de 1984, está publicado no livro História da Arte-Educação, de Ana Mae Barbosa (BARBOSA, 1986); e o texto "O desafio da formação de recursos humanos para a educação através da arte", de 1977, faz parte dos Anais do I Encontro Latino Americano de Educação Através da Arte. Assim, vamos nós também juntando nossa voz às outras vozes e fazendo mais forte essa cantoria e esse refrão.

Vou tomar os textos em ordem cronológica de aparecimento e fazer destaques de algumas passagens. Eles mesmos já são entremeados... eles mesmos fazem remessas entre si. Apenas vou ser mais um anteparo a fazer eco. Só que com a intenção de examinar os nossos movimentos, não os dela. Ela foi quem foi, ela disse o que disse. Aqui, pretendo explorar o que poderia ter sido feito e dito e, mesmo, o que foi dito e feito por nós, nesses anos depois. Vou procurar escapar da 
tentação de interpretar as citações, atribuindo um certo significado cabalístico e postiço às suas palavras. Pretendo me esquivar ao máximo de decifrações e decodificações de mensagens visionárias ou proféticas em seus escritos. E também vou tentar desviar da tendência de identificar correspondências e remessas lineares entre suas idéias e as de outros autores. Tentarei experimentar a admiração ante suas palavras. Deixar-me tomar de surpresa e entusiasmar-me com seus dizeres, fazendo uma leitura heurística dos seus textos. Mas não sem sinalizar o óbvio, apontando parecências e similitudes: a neutralidade me é impossível. E o alinhamento com a análise de Lucimar Bello, inevitável. Enfim, vou permitir que a voz de Noêmia Varela faça surgir outras vozes, de outros autores, de outras épocas. Fazer de sua voz uma voz que não vem antes nem depois, mas junto-com. Ressonâncias, talvez. Que vozes suscitam essa voz? Trarei algumas. Outras, deixo que vocês tragam, enquanto ouvem.

\section{O mestre-do-futuro - 1972}

No primeiro texto, também Noêmia Varela convoca outras vozes para falar. Começo por uma invocação que ela faz de Anísio Teixeira. Noêmia toma um artigo dele sobre a formação de professores, escrito em 1959, mais de dez anos passados, e pergunta: "qual a imagem mais objetiva desse novo mestre? Que fazer e saber são necessários à sua formação? E onde está a arte de levar o Homem à descoberta do novo mestre em si mesmo?" (VARELA, 2001a: 182). Será recorrente - nela e em nós - a pergunta fundamental sobre a formação de professores. A essa altura, ela ainda se refere aos professores em geral, não propriamente aos professores de arte. Não é pela arte de formar o mestre que ela pergunta, mas pela arte de levar o homem à descoberta do novo mestre em si mesmo. É um sentido de formação que faz dobrar-se o sujeito sobre si mesmo, é um sentido de auto-formação que nos aparece aí. Que fazeres e que saberes, pergunta ela, quase trinta anos antes do Relatório Delors ${ }^{4}$. Que fazeres e que saberes, pergunta ela, sem suspeitar que vamos atravessar décadas fazendo as mesmas perguntas e encontrando tão diferentes respostas.

À universidade brasileira cabe considerável parcela de compromisso no sentido de se efetuar o processo renovador necessário para o ensino criativo - seja em nível de currículo de sua Faculdade de Educação, aprimorando vocações definidas e reformulando a ação docente, seja em nível de pós-graduação como laboratório de alto gabarito de criatividade nos campos das artes, ciências físicas e sociais; no incentivo à tecnologia, à pesquisa e no aprofundamento dos estudos teóricos, captando dessa forma a expressão e o

\footnotetext{
4 DELORS, Jacques. Educação: um tesouro a descobrir (Relatório da Comissão Internacional sobre Educação para o Século XXI para a UNESCO). Brasília: UNESCO/ MEC; São Paulo: Cortez, 1999.
} 
pensamento criadores de sua população de mais de meio milhão de jovens através de cursos qualificados, vinculados à realidade brasileira e à específica necessidade de formar mestres que possam trabalhar no processo contínuo de reformulação, renovação, invenção e metamorfose do mundo. (VARELA, 2001a: 183)

Vemos aí a polêmica sobre o papel das Faculdades de Educação como aparelho de importante interferência crítica, como espaço privilegiado em termos do comprometimento com a formação docente, ao lado da pós-graduação, ainda bastante incipiente no Brasil, mas já sinalizada como pólo de formação do pesquisador. Vemos a preocupação com a realidade, o repertório e o acervo cultural e intelectual dos alunos como fonte privilegiada para a produção de conhecimento. Vemos a vontade de revolução, tão cara a $\mathrm{Kant}^{5}$, indicada como objeto mais significativo para essa instituição que é a universidade.

Recorrendo novamente a Anísio Teixeira, ela declara o propósito de uma "escola incluindo a nova orientação de educar cada um e não apenas selecionar os capazes, ou os suscetíveis de se ajustarem aos programas estabelecidos e compulsórios". (VARELA, 2001a: 184) Numa legítima reatualização do espírito escolanovista, o cada um expressa a preocupação com a singularidade do sujeito na sua formação. O ideário liberal deweyano transpira na intenção de viver a experiência, de educar pela particularidade da experiência e seus efeitos no indivíduo.

Pontuando a formação do professor, ela continua:

nessa perspectiva [de uma experiência criadora onde se prepara a previsão do futuro], como poderíamos trabalhar esse 'novo mestre'? Estimulando experiências que nos possam trazer soluções criativas, levando-as às tradicionais escolas para a desejada transmutação? Globalizando o esforço continuado de muitos, unidos no propósito de uma cooperação universal para a descoberta da solução mais condizente com nossa época para a integração na escola das conquistas técnico-científicas? E por que não atuar em todas as frentes? Nas velhas e novas estruturas, junto ao velhomestre, mestre-do-futuro. Este último, trabalhando desde sua infância, na perspectiva de seu devenir e na abertura de uma educação preventiva que totalize a capacidade criadora do Homem? (VARELA, 2001a: 184)

\footnotetext{
5 Essa idéia é exporada por Immanuel Kant na segunda dissertação, publicada em O Conflito das Faculdades. Lisboa: Edições 70, 1993.
} 
Mais uma vez, me parece importante apontar aí alguns rastros associáveis à tese kantiana de que o progresso se atualiza na vontade de revolução mais do que na revolução propriamente dita. E o que dizer desse "mestre-do-futuro, trabalhando desde a sua infância na perspectiva de seu devenir e na abertura de uma educação preventiva que totalize a capacidade criadora do homem"? (VARELA, 2001a: 184) Podemos fazer uma correspondência com a formação ao longo de toda a vida ou será forçar demais? Agregar à formação do professor a memória, a sua história de vida e seu saber experiencial. E o que são esses devenires, se não possibilidades, existências latentes e latejantes em si e nos outros?

Envolvê-lo também no processo criativo e, conseqüentemente, levá-lo à sua forma particular de educar, operar - no tempo e no espaço da sua vida - na construção da totalidade e unicidade de cada educando, em harmonia com todos os demais fatores que contribuem para o seu desenvolvimento. (VARELA, 2001a: 185)

Mais uma vez, a tácita intenção de alcançar um estado de felicidade coletiva, de bem estar, uma espécie de wellfare state. Nada muito diferente, em intenção, da idéia de realização ou de emancipação que nos acostumamos a bradar no fim do século vinte.

A terceira parte do texto se intitula "reflexões sobre uma forma nova de preparação do professor - características e possibilidades para a mudança". (VARELA, 2001a: 186) A tônica dessa secção também é aquela vontade de revolução, que aparece aqui como prontidão para a mudança. O movimento proposto (tanto para a formação do próprio professor quanto para sua atividade de formação) percorre o alargamento estratégico das dimensões da personalidade e o estendimento das fronteiras da experiência. Alargar as dimensões e estender as fronteiras, eis a tarefa que se põe a formação do professor (VARELA, 2001a). A ele caberá descobrir o outro em sua originalidade individual e em seus condicionamentos e pobreza simbólica. A idéia não é formar um especialista, mas proporcionar uma formação geral, diversificada e heterogênea (aparentemente paradoxal) que provoca o uso da imaginação e da invenção na meta da organização de experiências construtivas. Tornar o professor, ele mesmo um palco de experimentações. Ele mesmo um campo de possibilidades. Muita coisa ele pode ser, pode vir a ser. Assim como o outro é tudo e é nada, é original e singular e é pobreza simbólica. E se o outro o é, ele também pode sê-lo. 
"Não formamos o professor especializado em arte, mas indicamos ao educador o caminho para a mudança, a fim de descobrir, se lhe convier, a especialização". (VARELA, 2001a: 189) Fio de navalha sobre a superficialidade caótica da polivalência que se salva na idéia de multiplicidade. O professor polivalente de que fala Noêmia é o polivalente de sensações, de percepções, de experimentações. Longe de ser o faz-tudo, o falso policompetente que as primeiros tempos das novas Licenciaturas, curtas e plenas, em Educação Artística ajudaram a formar, o polivalente é aquele que tem muitas valências, muitas polaridades, muito mais que apenas o positivo ou negativo. A polivalência pretendida aqui se aproxima da idéia de interdisciplinaridade, muito forte no início dos anos setenta.

Também se fala em "artista transformado no artista-professor, inserido numa outra forma de trabalho criativo, capaz de captar sua sensibilidade, pensamento e ação criadores para renovação da escola". (VARELA, 2001a: 189) O artista se experimentando professor e experimentando os outros se experimentando. Sua vida é obra de arte, a vida dos outros é obra de arte, a vida dos outros e a sua vida são campos de experimentação. Talvez, enquanto a experiência criativa, o ensino de arte e a experimentação estética ficarem restritas à aula de arte, talvez não se tenha os efeitos possíveis.

"E se a era atômica em que estamos, começa a modificar nossas concepções de vida, tornando sonhos e ficções, realidades, conseqüentemente concluímos que haverá de surgir a escola criativa no processo da descoberta do 'novo-mestre'". (VARELA, 2001a: 192) O uso intencional dos plurais - sonhos, ficções e realidades - também denota a multiplicidade do mundo latente nessa visão de formação. Não há a realidade, mas realidades, sempre se fazendo, sempre proliferando. As rupturas modernas e o multifacetamento da cultura na transição entre os anos sessenta e setenta contribuem para que se dê asas à imaginação e à fabricação de algumas utopias um tanto românticas que muito em breve cairão por terra.

\section{Perigo à vista desarmada - 1973}

O que assusta a todos nós que acreditamos no papel primordial da educação neste período de conquistas grandiosas - sobretudo científicas e tecnológicas -, mas também de perdas catastróficas e danos insanáveis que caracterizam o mundo atual, é o problema da falta de qualidade da própria arte-educação hoje. Problema crescente já observado pelos que fazem arte-educação com seriedade e competência. (VARELA, 2001b: 220) 
Lucidez de sobra. Vale o que diz Foucault sobre o poder e a sociedade: é perigoso. E se é perigoso, a gente tem que prestar muita atenção, ser estrategista e não acreditar em nada espontâneo e plenamente bom. Tudo o que é, poderia estar sendo outra coisa. E se poderia é porque ainda pode. Assim, muita cautela com essa inconseqüência e irresponsabilidade que assola muitas salas de aula regulares, não regulares e irregulares, muitas oficinas e ateliês de alguma coisa. Ondas de modismos foram e continuam sendo freqüentes e, via de regra, acarretam inúmeras situações, como sensibilizações, releituras, etc.

Há exceções, é claro. Luta-se, na verdade, pela qualificação da arte-educação em todos os graus de ensino, na escola e em outros espaços alternativos. Mas, de modo generalizado, ainda vem sendo apregoada e posta em circulação na escola brasileira uma educação não poética, imatura, ingênua por vezes, e quase sempre bem mascarada. (VARELA, 2001b: 220)

A difícil tarefa de separar as boas intenções das efetivamente boas propostas de trabalho. O mais complicado é que todo mundo quer ser exceção. Ser diferente. Por nada, só para ser. Porque sabe que ser igual é ruim, que tem que ser original, singular, único, bem diferente. E é aí, nessa gratuidade imatura que começa a inconsistência que vai acabar contribuindo para a desqualificação. Para a estetização superficial, para a estilização rasa.

"É fácil constatar, entretanto, que a arte-educação sobrevive em muitas escolas apenas como um novo nome." (VARELA, 2001b: 220) Ah, os nomes. A guerra dos nomes. Educação pela arte, educação através da arte, educação em arte, educação artística, arte-educação, arte/educação, ensino de arte, ensino de artes, ensino das artes, maiúsculas, minúsculas, um universo.

"Reina embalada - em duplo sentido: dormindo em berço esplêndido e bem empacotada - em discurso sem pensamento divergente." (VARELA, 2001b: 220) $A h$, que saudade do tempo que se estudava de verdade. Do tempo que a gente lia livros inteiros. E que sublinhar era como debater e discutir com o autor. A essa altura já é possível perceber que a promessa esboçada pela Lei no. 5692/71 vai ser consumida pelo desgoverno geral que se estende pela década de setenta.

Continua a girar em torno de técnicas repetidas sem quaisquer conseqüências que levem o educando a criar, refletir e a viver de modo diferente. Prefere materiais de preços inacessíveis e desvinculados do meio ambiente, da natureza, do homem, sem possibilidades imprevisíveis. Visa 
à usura, à ambição de poder, à manipulação das idéias." (VARELA, 2001b: 221)

Materiais com possibilidades imprevisíveis: a vida não era assim também? Cada vez mais presenciamos gente que renuncia a si mesmo em favor de tornar-se algo ou alguém de acordo com algum padrão. Ainda que os padrões sejam muitos e que isso possa remeter a alguma forma de diversidade, continua valendo a idéia de que o padrão, o clichê, o estereótipo não têm possibilidades imprevisíveis. Mesmo os materiais já não tão caros, mais próximos do meio ambiente, da natureza e do homem, também eles muitas vezes viraram peça de repetição, ingrediente de receita.

E, mesmo dessa forma, vem sendo aceita
prazerosamente - por ignorantes do que seja a arte-
educação, pelos equivocados em sua escolha profissional e
que não passam de corpos estranhos no domínio da
educação, pelos mal-intencionados estruturados do
submundo da arte-educação. (VARELA, 2001b: 221)

Como boa parte das disciplinas do currículo escolar, também a educação artística sucumbiu ao modelo alienante do sistema hegemônico. Uma ideologia pautada no esvaziamento, na banalização, na reprodução de estereótipos vazios mascarados com uma falsa idéia de criatividade. Aquela perspectiva da polivalência entendida como multiplicidade é convertida em uma formação superficial e leviana. A rotina das escolas passou a ser governada pela arte como enfeite, como decoração.

Por tudo isso, a arte em educação aí está: em muitos lugares em sinal vermelho, não evoluída, não revolucionária e, assim sendo, sem a marca libertária, sem o espaço para a necessária iniciação no exercício do ato criador e da descoberta da forma, carente de dimensão filosófica. Logo, em minha ótica, sem a sua legítima atribuição de transformar o mundo, na parte essencial que lhe cabe, na arte de educar. (VARELA, 2001b: 221)

Poderíamos dizer que esse período representou o tempo em que se tirou a arte da arte-educação ${ }^{6}$.

\section{Existirá essa forma de educação? - 1977}

No contexto de um evento pioneiro no Brasil e na América Latina, capitaneado pela SOBREART (Sociedade Brasileira de Educação Através da Arte), criada em 1973,

\footnotetext{
${ }^{6}$ Paráfrase do título texto de Vincent Lanier, Devolvendo arte à arte-educação, publicado em BARBOSA, Ana Mae (Org.). Arte-Educação: leitura no subsolo. São Paulo: Cortez, 2002.
} 
Noêmia Varela faz uma contextualização pautada por duas balizas: o Plano a Médio Prazo (1977-1982), da UNESCO, que situava a ciência e a técnica a serviço do homem, e a Lei no. 5692/71, que tornou obrigatória a educação artística no currículo escolar. Sua expectativa é que "da emergência de um professor mais qualificado e criativo surgirão o mestre-artista e o artista-mestre". (VARELA, 1977: 54) No horizonte de suas considerações está o projeto de Herbert Read da educação através da arte, que afirma a tese de que a arte é a base da educação.

Suas considerações são parcimoniosas. Ela diz que,

não há modelo perfeito nem único, na educação criadora, para ser imitado e seguido - uma vez que cada educador sendo ele próprio singular e único como ser humano, tem o potencial necessário para encontrar, criar novos métodos e formas de ensinar, mais sensivelmente, dentro de seus limites e possibilidades. (VARELA, 1977: 54)

Esboça-se um pouco do perfil de autonomia do docente que deverá ser pensado então: uma dupla condição, o artista-mestre e o mestre-artista. O primeiro é aquele que vai proporcionar ao aluno a experiência criativa inusitada, a vivência do fazer imprevisível e surpreendente, sem as bases rígidas das prescrições, que vai apresentar a arte ao aluno; o segundo, por sua vez, será aquele que tomará a experiência artística como parâmetro para sua tarefa formativa, que vai tomar a experiência criativa como modelo de educação.

A proposta de Herbert Read

faz da educação uma arte e, desse modo, dá nova dimensão à preparação do arte-educador que essa forma de educar exige. Pede um processo criativo em educação. Como, então, formar professores para essa arte de educar? Atualmente, o panorama do ensino de arte na escola brasileira expressa muitas diferenças - de sistema para sistema, de escola para escola, de professor para professor. (VARELA, 1977: 55)

É esse contexto que, em certa medida, vai dar argumentos para que se pensasse naqueles Cursos Intensivos de Arte na Educação (CIAEs), promovidos pela Escolinha a partir de 1961, como referência para a formação de professores.

Quase trinta anos depois de iniciado o Movimento Escolinhas de Arte (MEB) no Brasil, Noêmia Varela revela sua apreensão e aponta claramente o seu potencial formativo, dizendo que "sabemos muito bem que uma instituição se expressa mais na qualidade de suas iniciativas do que na proliferação estereotipada de suas experiências" (VARELA, 1977: 55). Sua preocupação sempre foi com um parâmetro 
de rigor necessário para as "muitas e multifacetadas Escolinhas de Arte que surgiram no país" que foram aceitas pelo MEB como um desafio. A concepção que norteava a iniciativa era uma instituição "aberta à renovação, à crítica construtiva, como microlaboratório onde as idéias crescem, na espera - na oportuna espera do tempo e do vento para as grandes travessias" (VARELA, 1977: 55), "um centro experimental onde se cultiva e se acredita na educação como fonte de vida, de unidade" (VARELA, 1977: 56).

Sua posição, nesse evento, era a de continuar colocando sob avaliação as iniciativas anteriores, como o fizera em outros momentos, de modo a sempre assegurar caminho aberto para pensar a formação do professor pautada na descoberta de "plurimetodologias criativas", como ela dizia.

\section{Silêncio e trabalho! - 1984}

Em plenos anos oitenta, fim do período de ditadura militar, já com a perspectiva de uma Assembléia Nacional Constituinte se desenhando no horizonte, a USP realiza o I Simpósio Internacional da Arte-Educação. Nessa ocasião, Noêmia Varela expressa as suas preocupações:

A arte no ensino de $1^{\circ}$. e $2^{\circ}$. graus continua sem espaço, continua superficializada, sem uma linha filosófica que the dê unidade e força, e o arte-educador sem o desempenho desejado - embora habilitado - sem horizonte e ainda sem assumir o papel de agente transformador na escola e na sociedade. (VARELA, 1986: 12)

Aquele sonho inaugurado pela Lei no. 5692/71 mostrou-se comprometido por uma condição de realidade que o levou em outra direção.

Noêmia, então, faz uma fala que resgata a sua experiência com os CIAEs de 1961 a 1981. Ela retoma elementos já considerados em 1972 e coloca em questão alguns traços fundamentais dessa concepção: Mas, que devemos pensar da formação do arte-educador? Quais as relações da arte com a educação que poderão melhor delimitar o lugar e a natureza do processo de formação do arte-educador? O que dá mais a pensar sobre esta questão e que ainda não foi pensado? Que é necessário desaprender para encontrar o caminho mais sábio que nos leve à elaboração mais rica do processo de formação do arte-educador? (VARELA, 1986)

Perguntas dessa natureza vêm nos acompanhando até hoje. Especialmente se considerarmos o ideário da educação crítica, bastante potente a partir dos anos oitenta, trazendo uma tônica mais sociológica do que psicológica às discussões pedagógicas no Brasil e no mundo. As teorias da reprodução, as teorias da resistência, a nova sociologia da educação, a nova esquerda, as teorias críticas, 
todas elas contribuem para colocarmos em questão aquele ideal emancipatório que prometia a plena libertação do indivíduo através da educação.

Com muita propriedade, Noêmia coloca questões de extrema atualidade, o que faz dessa arte-educadora uma extemporânea e, ao mesmo tempo, nos dá a ver a obsolescência e o relativo anacronismo de nossos discursos. Ainda que pretendamos a constituição de uma aura pretensiosa de "vanguardismo", as questões que temos remetem ao que há de mais prosaico e elementar na história da arte-educação. Vamos criando novos nomes, novas roupagens, ares pósmodernos de uma alegria revolucionária francesa quase insuportável, arranjados por uma displicência filosófica da qual já nem nos envergonhamos.

Na verdade, precisamos de um caminho de sabedoria que nos conduza à apreensão de um processo de capacitação de recursos humanos mais autênticos, caracterizado por atitudes de desenvolvimento receptivo e contemplativo. (...) Sinto necessitar de silêncio e trabalho. (VARELA, 1986: 12)

Para consolidar a idéia, Noêmia Varela recorre a São João da Cruz: "o falar distrai, o silêncio e o trabalho concentram os pensamentos e fortalecem o espírito". (VARELA, 1986: 13) A experiência acumulada na história do MEB, o testemunho do período militar, o silenciamento de projetos como o de Paulo Freire, o afrouxamento dos projetos no período da abertura, são vários os fatores que provavelmente contribuem para essa posição de mais cautela ante qualquer iniciativa mais leviana ou ruidosa.

Ela acredita que não é o modelo institucional, não é o programa que garante o sucesso da proposta, mas o comprometimento do sujeito com sua própria formação e com a do outro.

Penso que é preciso não substituir o tipo de formação atual por outra, pois logo se mostraria precário e conservador. Parece-me que o mais fundamental está em se arquitetar a formação do arte-educador a partir do princípio que deva estar sempre em desenvolvimento, na abordagem dos fenômenos da sorte, da educação, da filosofia, enfim, do conhecimento teórico e prático que a enriqueça e fale das conquistas do homem como ser inventivo, fértil em sua imaginação e capacidade de construir o mundo. Que se forme um arte-educador sempre a serviço do ser humano e não da instituição. (VARELA, 1986: 26) 
De certo modo, podemos suspeitar que sua posição responde à idéia de que o desenvolvimento estético resulta da focalização dos meios e dos processos educativos, consistindo antes uma experiência singular.

\section{Um campo interminável}

Chego ao final deste texto reiterando aquela idéia da relatividade crítica dos valores e princípios que norteiam o trabalho do professor.

E sirvo-me de algumas considerações de Robert Saunders feitas nesse mesmo Simpósio da USP, em 1984. Ele afirma que a arte é um fenômeno cultural, inventada para satisfazer algumas necessidades humanas. Assim como as necessidades humanas mudam através dos tempos, também mudam os objetivos da arte (SAUNDERS, 1986). Mas não é que esses objetivos ou necessidades sejam suprimidos ou substituídos, uns pelos outros. Uma vez estabelecidos os objetivos para a arte ou para a arte-educação dentro de uma cultura, eles permanecem e se acumulam. Novas finalidades satisfazem novas necessidades porque a cultura e a sociedade se transformam. Mas as finalidades anteriores não desaparecem, apenas mudam seu status (SAUNDERS, 1986).

A pergunta que ele faz e que eu faço questão de trazer para este momento é: "que finalidade terá a arte-educação no que diz respeito exclusivamente à arte?" (SAUNDERS, 1986: 68)

Trago essa pergunta porque me parece que a finalidade que se coloca para a arteeducação, neste século vinte e um, já não diz mais respeito exclusivamente à arte. Porque entendo que, dada a complexidade das nossas formas de organização social e de produção da nossa existência, compete à arte-educação uma parcela significativa da tarefa crítica de contribuir para que o sujeito se pense. Porque acredito que precisamos devolver a estética à arte-educação, no sentido de proporcionar a experiência de um processo e um percurso críticos que levem professor e aluno a se aproximarem de compreender como chegaram a ser o que são.

E assim, aventurar-se na perpétua aventura de explorar o interminável campo da relação entre a educação e a arte. 


\section{Referências}

BARBOSA, Ana Mae (Org.) História da Arte-Educação. São Paulo: Max Limonad, 1986.

BARBOSA, Ana Mae. Arte Educação no Brasil: do modernismo ao pós-modernismo. Revista Digital Art\& - Número 0 - Outubro de 2003 (Disponível em: www.revista.art.br/site-numero-00/anamae.htm)

BAUMAN, Zigmunt. Modernidade Líquida. Rio de Janeiro: Zahar, 2000.

FRANGE, Lucimar Bello Pereira. Noêmia Varela e a arte. Belo Horizonte: C/Arte, 2001.

OELKERS, Jürgen. A educação para o bem: potencial de legitimação da pedagogia geral. Educação. Porto Alegre, ano XXX, n. 2 (62), mai/ago, 2007.

PEREIRA, Marcos V. Utopias contemporâneas para a vida coletiva. Travessias.

Cascavel, $\quad$ n.2, 2008 em: http://www.unioeste.br/prppg/mestrados/letras/revistas/travessias/ed_002/cultura Lutopiascomtemporaneas.pdf

PEREIRA, Marcos Villela. A estética da professoralidade. 20a Reunião Anual da Associação Nacional de Pós-Graduação e Pesquisa em Educação - ANPED. GT-8 (Formação de Professores). Caxambú. 1997.

PEREIRA, Marcos Villela. Estética da professoralidade: um estudo interdisciplinar sobre a subjetividade do professor. São Paulo: PUCSP, 1996. Tese (Doutorado em Educação), PPG Educação - Supervisão e Currículo, 1996.

SAUNDERS, Robert. Fazer arte-educação faz uma diferença no mundo. In: BARBOSA, Ana Mae (Org.). História da Arte-Educação. São Paulo: Max Limonad, 1986.

VARELA, Noêmia. A formação do arte-educador no Brasil In: BARBOSA, Ana Mae (Org.). História da Arte-Educação. São Paulo: Max Limonad, 1986.

VARELA, Noêmia. Criatividade na escola e formação do professor. In: FRANGE, Lucimar Bello. Noêmia Varela e a arte. Belo Horizonte: C/Arte, 2001a. 
VARELA, Noêmia. Movimento Escolinhas de Arte: imagens e idéias. In: FRANGE, Lucimar Bello. Noêmia Varela e a arte. Belo Horizonte: C/Arte, 2001b.

VARELA, Noêmia. O desafio da formação de recursos humanos para a educação através da arte. In: Anais do I Congresso Latino Americano de Educação através da Arte. Rio de Janeiro: SOBREARTE, 1977.

WELSCH, Wolfgang. Estetização e estetização profunda ou: a respeito da atualidade do estético nos dias de hoje. Porto Arte. Porto Alegre, v.6, n.9, mai, 1995.

WELSCH, Wolfgang. Mudança estrutural nas Ciências Humanas: diagnóstico e sugestões. In: Educação. Porto Alegre, ano XXX, n. 2 (62), maio/ago, 2007. 